\title{
Atlantic bluefin tuna (Thunnus thynnus) in Greenland - mixed-stock origin, diet, hydrographic conditions and repeated catches in this new fringe area
}

\author{
Jansen, Teunis; Eg Nielsen, Einar; Rodríguez-Ezpeleta, Naiara; Arrizabalaga, Haritz; Post, Søren; \\ MacKenzie, Brian R.
}

Published in:
Canadian Journal of Fisheries and Aquatic Sciences

Link to article, DOI:

10.1139/cjfas-2020-0156

Publication date:

2021

Document Version

Peer reviewed version

Link back to DTU Orbit

Citation (APA):

Jansen, T., Eg Nielsen, E., Rodríguez-Ezpeleta, N., Arrizabalaga, H., Post, S., \& MacKenzie, B. R. (2021). Atlantic bluefin tuna (Thunnus thynnus) in Greenland - mixed-stock origin, diet, hydrographic conditions and repeated catches in this new fringe area. Canadian Journal of Fisheries and Aquatic Sciences, 78(4). https://doi.org/10.1139/cjfas-2020-0156

\section{General rights}

Copyright and moral rights for the publications made accessible in the public portal are retained by the authors and/or other copyright owners and it is a condition of accessing publications that users recognise and abide by the legal requirements associated with these rights.

- Users may download and print one copy of any publication from the public portal for the purpose of private study or research.

- You may not further distribute the material or use it for any profit-making activity or commercial gain

- You may freely distribute the URL identifying the publication in the public portal 


\section{Atlantic bluefin tuna (Thunnus thynnus) in Greenland - 2 mixed-stock origin, diet, hydrographic conditions and 3 repeated catches in this new fringe area}

5 Teunis Jansen ${ }^{1,2,}{ }^{*}$, Einar Eg Nielsen², Naiara Rodriguez-Ezpeleta ${ }^{3}$, Haritz

6 Arrizabalaga4, Søren Post ${ }^{1,2}$ and Brian R. MacKenzie ${ }^{2}$

7

8

1) GINR - Greenland Institute of Natural Resources, Kivioq 2, P.O. Box 570, 3900 Nuuk, Greenland

2) DTU Aqua - National Institute of Aquatic Resources, Technical University of Denmark, Kemitorvet, Building 202, 2800 Kgs. Lyngby, Denmark

3) AZTI, Marine Research, Basque Research and Technology Alliance (BRTA). Txatxarramendi ugartea z/g, 48395 Sukarrieta - Bizkaia

4) AZTI, Marine Research, Basque Research and Technology Alliance (BRTA). Herrera Kaia, Portualdea z/g, 20110 Pasaia - Gipuzkoa

\footnotetext{
Corresponding author: Teunis Jansen; GINR - Greenland Institute of Natural Resources, Nuuk, Greenland; Tel.: +4530667840; Fax:+4533963333; E-mail address: Tej@aqua.dtu.dk.
}

Keywords: bluefin tuna, Greenland, Irminger Sea, mackerel, Scomber scombrus, temperature, prey, genetics 


\section{Abstract}

25 Based on collaboration with the Greenlandic fishing fleet, we document the presence of Atlantic

26 bluefin tuna (Thunnus thynnus) in most years from 2012 to 2018 in the waters east of Greenland

27 (northern Irminger Sea). In total, 84 individuals have been registered as bycatch in the commercial

28 fisheries in Greenland waters, which indicates that the first catch of 3 individuals in 2012 was not a

29 single extreme observation, but that East Greenland waters have become a new outer limit of an

30 expanded tuna habitat. Genetic analyses indicate that specimens from this region are mostly of

31 Mediterranean origin with a small proportion originating from the Gulf of Mexico stock. Stomach

32 content analysis suggests that the main prey is Atlantic mackerel (Scomber scombrus). The tunas

33 ranged in size from $140-270 \mathrm{~cm}$ corresponding to an estimated age range of 5-16 years; most were

34 probably mature. The wide size-age range suggests that many year-classes are participating in the

35 migration to this region. Sea temperatures during summer have been above the long-term average in

36 recent years of interest. Summer residence of bluefin tuna in the region could be due to a

37 combination of increasing temperatures and higher overall abundances of both bluefin tuna and a key

38 prey species (Atlantic mackerel).

39

40

41

42

(c) The Author(s) or their Institution(s) 


\section{Introduction}

Distributions and migratory behaviour of species depend on a range of abiotic and biotic factors. These include properties of the environment that directly affect bioenergetics and physiology of the species, as well as density-dependent abundance-distribution effects, and the presence of interacting species such as prey, predators and competitors (MacCall, 1990; Heithaus et al., 2008; Olafsdottir et al., 2019). During the past decades, there have been numerous reports of changes in spatial distributions, and phenologies of a variety of species at different trophic levels and functional groups (plankton, benthos, fish; zooplanktivores; piscivores) from the tropics to polar seas (IPCC, 2019). The primary factor associated with many of these documented changes is rising temperatures associated with global climate change (IPCC, 2019).

Changes have occurred in waters east of Greenland in the Irminger Sea-Denmark Strait region. Three Atlantic bluefin tuna (Thunnus thynnus), were reported in the area in 2012 (MacKenzie et al., 2014), which is several hundreds of $\mathrm{km}$ beyond their nearest previously documented northern summer feeding range (Iceland Basin: Fromentin et al. 2013; Olafsdottir et al. 2016; northern Newfoundland: Mather et al. 1995). This species, caught as bycatch in the mackerel fishery in the Irminger Sea, is a large highly migratory top predator which migrates northwards in summer for feeding after spawning in more temperate regions (Mediterranean Sea, Gulf of Mexico and the recently discovered Slope Sea (Richardson et al., 2016)). In the northern regions (e.g., North Sea, Norwegian Sea and Iceland Basin), it preys on pelagic and mesopelagic prey, including herring, mackerel, squids and barracudinas (Tiews, 1978; Olafsdottir et al., 2016). The appearance of Atlantic bluefin tuna in Greenland waters in 2012 coincided with unusually warm temperatures over a large area of the east Greenland region (MacKenzie et al., 2014). These warmer temperatures may have been due to changes in ocean circulation and atmospheric warming in the region. The region is characterized by influx of relatively warm water via the Irminger Current and north Atlantic Drift from the south and delimited by the southward flow of cold Arctic water associated with the East Greenland Current (Astthorsson et al., 2012; Olafsdottir et al., 2019). Alternatively, or perhaps synergistically, the changes may have been associated with general warming of the oceans. 
76 Warm temperatures in the same region have led to a major expansion of habitat for another pelagic migratory species, Atlantic mackerel (Scomber scombrus) (Jansen et al., 2016). This species has spread from the European northwest continental shelf-slope waters north and westwards towards the Faroe Islands, Iceland and East Greenland during the 2000s-2010s (Astthorsson et al., 2012; Jansen et al., 2016; Nøttestad et al., 2016). This range expansion is believed to be due to a complex interaction between temperatures, mackerel population dynamics, and the availability of zooplankton (Trenkel et al., 2014; Jansen et al., 2016; Olafsdottir et al., 2019)). One potential prey species (mackerel) has therefore become more abundant in waters east of Greenland. Both the Atlantic bluefin tuna and mackerel have been absent or very rare in this region until recently. In the 1990s, mackerel has sporadically been caught in low numbers around Iceland (Astthorsson et al., 2012) whereas few Atlantic bluefin tuna has been caught in a Japanese long line fishery near the Greenlandic EEZ (ICCAT, 2018). The overall biomasses of both species have been rising during the past 10-15 years according to stock assessments (ICCAT 2018; ICES 2019). As Atlantic bluefin tuna is relatively new to the region, its presence is demonstrating new migration behaviour and habitat use which deserve documentation and description to help understand factors affecting its distribution and ecological role, stock mixing, as well as the general dynamics of the marine ecosystem in this region. Given that there are two assessed stocks having different biomasses, demographics and fishing regulations, it is important for fisheries managers to know and understand the extent of stock distributions and potential mixing throughout the species range (Rooker et al., 2007; ICCAT, 2017a). The population origin of the tuna which appears in East Greenland is presently unknown.

In this study, we document the presence of Atlantic bluefin tuna in waters off East Greenland (Irminger Sea) in the years 2012 - 2018. We present biological sampling of size distributions, stomach contents and genetic analyses in the area. Stomach samples provide insight to the trophic relationships in the northern foraging areas for which no data are available since 1999 (Olafsdottir et al., 2016). The genetic analysis provide information about Mediterranean or Western Atlantic origin. Our study therefore contributes with new ecological knowledge of Atlantic bluefin tuna in a new region and extends current understanding of migration behaviour, habitat use, trophic role and stock mixing. 
108 Materials and methods

109

110

\section{Tuna observations and stomach content}

Vessels longer than 9.4 meters fishing in Greenlandic waters are required by law to report catches (including bycatches) in a logbook and send it to the Greenland Fisheries License Control Authority (GFLK) (GFLK, 2014). Discarding is illegal. The logbooks contain the dates and positions of the catches. These data were obtained from the GFLK database "Luli" on the $6^{\text {th }}$ of August 2019. In 2019 and 2020, the pelagic fishery for mackerel ended exceptionally early because of a reduction in the mackerel migration into Greenlandic EEZ. To encourage reporting and sampling of the bycatches, we have met with vessel owners and skippers before and after the mackerel fishing season (main pelagic fishery in Greenland) since 2014. During these meetings, we urged the skippers to measure the length and weight of each tuna, to sample stomachs for diet analysis, and muscle tissue for genetic analysis. Lengths were measured as total lengths (TL) from tip of snout to end of tail, and often rounded up or down to the nearest $10 \mathrm{~cm}$. The weight was sometimes measured and sometimes estimated, but we have no valid information on which weights were measured and which were estimated, except for three individuals captured in 2012 whose weights were estimated to be ca. $100 \mathrm{~kg}$ (MacKenzie et al. 2014). Because of these uncertainties, weight data, except for the 2012 captures for which length information is missing, were not used in our analyses. For the individual tunas, whose length was measured, we estimated weight from the available length measurements. However, available length weight relationships for bluefin tuna in adjacent regions, including the one used by the ICCAT bluefin tuna assessment group (ICCAT, 2017a), are based on straight fork length (SFL). Similarly, the currently used age-length relationship by the ICCAT bluefin tuna assessment working group is also based on fork length. In order to achieve comparable length and weight measurements with other regions and attain information on age we converted the data. Total lengths were converted to straight fork length using the relationship:

$\mathrm{SFL}=6.47+0.9554 * \mathrm{TL}$

based on 1699 individual tunas spanning a length range of ca. 120-260 cm caught in Spanish trap fisheries during 1956-61 (Rodríguez-Roda, 1964).

Given the estimated SFL, we calculated whole weights (W) using a previously-derived straight fork length - whole weight relationship for bluefin tuna in the northeast Atlantic and Mediterranean Sea (Rodriguez-Marin et al., 2015): 
140 (SFL in $\mathrm{cm}$ ). This relationship is based on sampling during all months of the year (Rodriguez-Marin et

141 al., 2015).

142 Ages were estimated by re-arranging the age-length relationship (Cort, 1991) used in the 2017 stock assessment (ICCAT, 2017a):

$144 \quad L=319 *\left(1-e^{(-0.93(t+0.97))}\right)$

These calculations allowed us to estimate weights and ages of the bluefin tuna captured in east Greenland waters. Similarly, for the three tunas whose weights had been estimated in 2012, we derived straight fork lengths and ages. The total number of tunas for which size and estimated age information was available was 49. Bluefin tuna spawning stock biomass (SSB) was estimated by ICCAT (ICCAT, 2017a). Bluefin tuna abundance index in East Greenland was, for discussion purposes, proxied by the catch in numbers per year in relation to the mackerel catch per year. The mackerel catch was chosen as the measure of effort instead of e.g. trawl-hours because the pelagic mackerel fishing fleet developed over the years as experience was gained with pelagic trawling in Greenland, and with variable participation of experienced foreign skippers.

Whole stomachs from 18 individual tunas in 2014 (10), 2015 (1) and 2017 (7) (table 1) were frozen onboard and shipped to the Greenland Institute of Natural Resources (GINR) for analysis. The sampling was done by the fishermen and, despite guidance on sampling procedures by scientists before the fishing season, can best be described as opportunistic and random in the sense that it was done where practically possible by the most compliant fishermen. In the laboratory, stomachs were thawed until they could be opened, and the prey items could be sorted into taxonomical groups, counted and weighed. Digestion stage were evaluated according to two criteria: 1. Light or no visible digestion, 2. Digesting i.e. skin from prey fish is absent and, in some cases, only a backbone was present. Backbones with or without remains of tissue were, in all cases, assigned to species because prey with similar sizes and appearances in less digested states were present in various degrees of digestion. It was the impression of the authors (TJ and SP) that sufficient comparable material were present to assign the remains to species. However, genetic identifications of the most digested prey were not performed, so these assignments could not be verified. 
DNA was extracted from muscle samples of 34 bluefin tuna caught in 2014 (21), 2015 (7) and 2017 (6) (table 1) using the E.Z.N.A.TM kit (Omega Biotek, Norcross, Georgia, USA). Sampling was opportunistic and random as described for the stomachs. SNP genotyping was conducted using the BiomarkTM HD platform (Fluidigm) and 96.96 Dynamic Array IFCs. We used a newly developed, genetic stock identification panel (Rodríguez-Ezpeleta et al. 2019) consisting of 96 highly discriminatory Single Nucleotide Polymorphisms (SNPs) for assigning fish back to the genetic populations from the two well-known spawning grounds - Gulf of Mexico (GOM) and Mediterranean Sea (MED). Individuals sampled in Greenlandic waters were assigned back to either spawning area based on genetic baseline samples (from Rodríguez-Ezpeleta et al. 2019) consisting of larvae, young of the year and spawning adults from GOM and MED. Assignment was conducted with the GeneClass2 software (Piry et al. 2004) using a minimum assignment score criterion of $80 \%$ for positively inferring population of origin. Individuals with lower assignment scores were classified as "unassigned".

\section{Hydrographic data}

A dataset of historic Sea Surface Temperatures (SST) from 1870 - 2019 was created by the Hadley Centre using the interpolation procedure described by Rayner et al. 2003. The so-called HadISST1 temperatures are based on in situ measurements and contain global monthly estimates of SST at $1^{\circ}$ longitude $\times 1^{\circ}$ latitude resolution (Rayner et al., 2003). We obtained this dataset from the Hadley Centre (www.metoffice.gov.uk/hadobs/hadisst) on June 17, 2019. We used August SST as a general indicator of thermal conditions in the region, as this is the month when temperatures are warmest, the mackerel fishing is concentrated and bluefin tuna have been caught in the region. We averaged the August SST in each grid cell for the years 2012-2019 and produced a map using these averages to visualize the spatial variability of SST in the area and in relation to the positions where bluefin tunas were caught during this time period.

We derived two indicators of long-term variability of thermal conditions to put the recent temperatures into historical context. One indicator is the time series of mean August SST by year for an area within the Irminger Current. This polygon $\left(63^{\circ} \mathrm{N} 35^{\circ} \mathrm{W}, 63^{\circ} \mathrm{N} 25^{\circ} \mathrm{W}, 65.5^{\circ} \mathrm{N} 25^{\circ} \mathrm{W}, 64.8^{\circ} \mathrm{N}\right.$ $30^{\circ} \mathrm{W}$ ) was selected so that it did not include the area near the Arctic front (the front between the warm Irminger Current and the cold East Greenland Current). This was done to ensure that the time series reflects the SST in the Irminger Current, and not the relative position of the Arctic front. 
199 A second indicator is an area estimate of thermal habitat covering a wider geographic region, thereby

200 potentially including sea areas through which bluefin tuna may have migrated to reach the locations

201 where they were captured. This area is bounded by $58-70^{\circ} \mathrm{N}$ and $20-45^{\circ} \mathrm{W}$, and was defined as the

202 sea surface areas whose temperature exceeded 11 and $8{ }^{\circ} \mathrm{C}$. We use two temperatures because the

203 lower temperature preference of bluefin tuna has not yet been determined with certainty. For

204 example bluefin tuna commonly experience colder temperatures (e. g., $2-5^{\circ} \mathrm{C}$ ) for shorter periods (e.

205 g. during dives), but have access to warmer water for recovery (Block et al. 2001; Teo et al. 2007).

206 Temperatures in the $8-11^{\circ} \mathrm{C}$ range are however close to those at the surface in northern feeding areas

207 (e. g., Norwegian Sea, southern Gulf of St. Lawrence; Canada) when bluefin tuna begins emigrating in 208 the autumn to warmer regions (vander Laan et al. 2014; MacKenzie and Myers 2007), and are 209 therefore probably similar to those which the species can tolerate for long periods of time (weeks210 months) without severe physiological stress. This range is also similar to the lower temperature 211 tolerance derived from probability of occurrence maps (Fromentin et al., 2013) and other thermal 212 habitat information (Boyce et al., 2008). Running means of the time series were calculated and 213 spanned 5 years, except for the second to first and second to last that were calculated over 3 years.

214 Welch Two Sample t-test was used to test if the mean temperature after 1996 differed from the mean 215 of from 1870 - 1996.

\section{Mackerel data}

217 Mackerel has been surveyed annually in East Greenland waters since 2013 as part of the International 218 Ecosystem Summer Survey of the Nordic Seas (IESSNS) (Nøttestad et al., 2013, 2019). The survey uses 219 stratified random sampling with a "Mulitpelt 832" pelagic trawl. At each station, a surface trawl was 220 towed for approximately $30 \mathrm{~min}$ at a speed between 4 and 5 knots. Vertical opening of the trawl was 221 typically 30-40 m. The trawl catch was identified to species and weighted. Specimens representing the 222 whole catch fraction where length and weight measured, and otoliths were extracted for age 223 determination. In total, 182 surface trawl stations have been taken in Greenland EEZ from 2014-2020. 224 Results from the survey (swept area estimate, area, and total estimate in tonnes) are reported 225 annually by Exclusive Economic Zone (EEZ) in annexes or working documents in the ICES WGIPS 226 reports (see ICES, 2019 for the latest report). Since 2014 this has included the Greenland EEZ. 
228

\section{Results}

84 Atlantic bluefin tunas were registered as bycatch in the mackerel trawl fishery in East Greenland in five different years from 2012 to 2018 (Table 1). All were caught in the Irminger Sea in East Greenland during late summer, between August $11^{\text {th }}$ and September $16^{\text {th }}$ (Figure 1). No tuna were caught prior to 2012, or in the last two years (2019 and 2020). The sizes (estimated straight fork lengths) of the tunas ranged from $1.4 \mathrm{~m}$ to $2.6 \mathrm{~m}$ (Figure 2a). Only 7 of the 49 length estimated specimens were shorter than $2 \mathrm{~m}$; the rest were between 2.0 and $2.7 \mathrm{~m}$. This corresponded to ages from ca. 5-18 years (mean $=12 ; \mathrm{SE}=0.4)$. In weight, the tunas were estimated to range from 53 to $329 \mathrm{~kg}$, with 7 specimens below $130 \mathrm{~kg}$, and the remaining 42 between 142 and $329 \mathrm{~kg}$ (Figure 2b).

\section{Stomach content}

Stomach content analysis of 18 tunas indicated that Atlantic mackerel was the primary prey as 8 of the tuna stomachs contained solely Atlantic mackerel. One tuna stomach contained a mixture of Atlantic mackerel and myctophids (family Myctophidae), and two stomachs solely myctophids. 8 of the stomachs were empty. In summary, $98 \%$ of the prey weight were mackerel, while $2 \%$ were myctophids. 67 of the 72 mackerel found in the stomachs were only slightly digested. These mackerel had an average weight of $0.44 \mathrm{~kg}$, corresponding to large mature mackerel of 6 - 9 years and $36-38$ cm pinched tail length (Hansen et al., 2018; ICES, 2018). All myctophids were partly digested.

\section{Genetic analysis}

DNA was successfully extracted, amplified and genotyped from muscle tissue for 34 of 36 samples. Of the 34 individuals, 25 were genotyped at all 96,8 at 95 and one at 94 SNP markers. 30 individuals were assigned back to population of origin with an assignment score of above $80 \%$, while four specimens were unassigned. Three individuals were assigned to GOM, two from 2014 (both with 100\% probability) and one from 2017 (probability score of 83\%), while the remaining 27 were assigned to MED (probability scores ranging between $83 \%$ and $99 \%$ ).

\section{Hydrographic conditions}

The tunas were caught in the northwestern extreme of the Irminger Current (Figure 1) close to the Arctic front. The in situ temperature at the exact times and places were not known. SST in the region where bluefin tunas were caught were ca. $8-10{ }^{\circ} \mathrm{C}$ (Figure 1). The SST in the warmest month (August) increased substantially in the late 1990s (Figure 3a). SST was significantly higher in 1997-2019 (t-test, 
$p<0.001)$ compared to 1870-1996. However, two of the last four years (2016 and 2018) were colder than the long term average.

Estimates of the size of the area of thermally suitable habitat in east Greenland (defined as SST> 8 or $11^{\circ} \mathrm{C}$ ) followed a similar historic development as the SST (Figure 3b). For example, the area was only below average in one year since 2003 (threshold SST $=8^{\circ} \mathrm{C}$ ). The sizes of the areas with temperatures $>8$ and $>11{ }^{\circ} \mathrm{C}$ were significantly correlated $\left(r^{2}=0.68 ; p<0.001\right.$; Pearson's productmoment correlation).

\section{Discussion}

We have documented that Atlantic bluefin tuna have become a near-annual seasonal guest in east Greenlandic waters since 2012. This observation indicates that the single catch of 3 specimens in 2012 was not a unique phenomenon but likely part of a wider and multi-annual population- or species-level change in migration behaviour and habitat use. The reasons for such a change could include both abundance changes of the tuna and their prey as well as oceanographic condition. This is discussed further below. The recent pattern of annual seasonal occurrence is evident despite the unintentional nature of the data source and collection method: that is, the presence is documented only from monitored bycatches in commercial fisheries and does not originate from targeted bluefin tuna surveys or fisheries. On this basis, we cannot estimate the total abundance in the area, extent of the season (the season of the mackerel fishery starts in mid June and ends in mid September (Jansen et al., 2016)), or the total spatial distribution of the Atlantic bluefin tunas in this region because the fishing vessels involved were targeting other species in a limited time and area. The capture of bluefin tunas in mackerel fishery hauls is consistent with the known diets of bluefin tunas in northern feeding areas: mackerel are an important prey species in many of these areas (Tiews, 1978; Chase, 2002; Pleizier et al., 2012), and it is likely that Atlantic bluefin tuna in east Greenland waters were captured while foraging directly on mackerel schools (as also supported by our limited stomach sampling data), or were within close proximity to such schools. The presence of mackerel as far south as Cape Farewell (Jansen et al., 2016) suggests that tunas could have been present further south than where we have documented them from the mackerel fishery.

\section{Stomach content and trophic interactions}


289 Our stomach analysis shows that the sampled bluefin tuna were feeding on mackerel and rarely on 290 other species (mesopelagic fishes: $2 \%$ of the diets by weight). The analysed stomachs were limited to 291 a very small number and may not be representative of the whole population in the region. Some mackerel found in the stomachs could have been from net-feeding during capture, which is a general problem with analysis of stomach content of predatory fish. However, we suspect that this phenomenon was limited or not present because mackerel were observed in all stages of digestion.

The extreme rarity of prey species other than mackerel in the diets represents a major dietary and trophic difference from bluefin tunas $(\mathrm{N}=421)$ captured in the Iceland Basin in 1998-1999. The latter tunas consumed a diet dominated by European squid and a variety of barracudina species along with other mesopelagic fish and squid species. Mackerel on the other hand were absent (Olafsdottir et al., 2016), as could perhaps be expected because the mackerel was still rare in the region at that time (Astthorsson et al., 2012; Olafsdottir et al., 2019). An additional difference in the foraging behaviour between these two regions is the proportion of individuals with and without prey in the stomachs. In our samples from the northern Irminger Sea, $55 \%$ contained prey, whereas $86 \%$ of the tunas captured in the Iceland Basin had prey in their stomachs (Olafsdottir et al., 2016). In general, the share of bluefin tuna individuals having prey in stomachs ranges from 39-91\% in different feeding studies (summarized in (Olafsdottir et al., 2016)), so the feeding incidence of the bluefin tuna investigated in this study, although based on a lower sample size compared to that for the Iceland Basin, is within the range observed previously in other areas.

We have not found strong evidence of deep dives for mesopelagic foraging in east Greenlandic waters. Mesopelagic foraging may have been limited because an alternative abundant, lipid-rich prey

312 such as mackerel was available. Mackerel are distributed at shallower depths (down to 30-40 m;

313 (Olafsdottir et al., 2019)) and in warmer waters than mesopelagic species (several 100s m, although 314 they do rise to the top $50 \mathrm{~m}$ during the night; (Jansen et al., 2019)) in this region and may be less 315 costly energetically to pursue, capture and consume due to shallower diving required. The energetic 316 benefits and costs of feeding on different prey types needs further investigation. Furthermore, 317 additional stomach samples from bluefin tuna are needed to derive more comprehensive and 318 representative dietary information. New investigations (e. g. tagging studies to resolve vertical 319 migration behaviour; stomach sampling including isotope and DNA-based approaches; process-based 320 foraging models) will help clarify the trophic role and feeding behaviour of tunas in this region. 
322 There is currently much scientific and public interest in the level of ingestion of plastic by marine consumers (ref.). However, we detected no large (i. e. $>1 \mathrm{~cm}^{2}$ ) pieces of plastic in these stomachs.

\section{Size and age distributions}

The range of sizes and estimated ages of the Atlantic bluefin tunas caught near Greenland suggests that they were most likely mature, given the ICCAT stock assessment and the likely geographic origin of most of these specimens (i. e. east Atlantic-Mediterranean). The ages were estimated to be ca. 518 years (mean $=12 ; \mathrm{SE}=0.4$ ), indicating individuals born in 1998-2013. Resolving this into specific year classes is uncertain because no direct aging was done. The results suggested that the dominant yearclasses were 2001 and 2002 (10 individuals each), followed by the $2004(\mathrm{~N}=6)$ and 2003 and 1999 yearclasses ( 5 individuals each). The dominance of yearclasses in the early 2000s may reflect the overall strength of several of these yearclasses as seen in other bluefn tuna catch time series, and in stock assessments for both the eastern and western stocks (ICCAT 2017). In general, however, the range of sizes and ages indicates that many cohorts have discovered the foraging area east of Greenland. This discovery or learning process by which new migration behaviours develop is poorly documented and probably complicated, possibly including social interactions within and among cohorts (De Luca et al., 2014; Petitgas et al., 2010).

The size range of bluefin tunas captured near East Greenland is broader than that seen in some other northern feeding areas. For example, the size range in the Skagerrak-Kattegat juncture (DenmarkSweden) in 2017-2019 during tagging operations was 185-266 cm curved fork length ( $N=159)$ and dominated by yearclasses from ca. 2005 (Birnie-Gauvin et al., 2018, 2019; MacKenzie et al., 2018). The tuna sample from near Greenland includes therefore smaller individuals than caught, tagged and released so far in the Skagerrak-Kattegat. However, smaller individuals similar in size to some of those captured in East Greenland have also been common in the past in waters near Denmark, Germany, Norway and Sweden (Hamre, 1958; Hamre et al., 1966; Mather et al., 1995; MacKenzie and Myers, 2007). New studies of the size distribution of bluefin tunas in the newly occupied summer foraging areas such as East Greenland, Norwegian Sea and Skagerrak-Kattegat are needed to understand potential size-based differences in spatial habitat use and migration behaviour.

\section{Mixed stock composition}

Our genetic results revealed that individuals from both the eastern and western Atlantic populations are present in the region, although most individuals were assigned to the eastern population. This 
could indicate that the foraging area east of Greenland constitutes a mixed-stock feeding area, similar to most fished areas in the North Atlantic and with the estimated proportions comparable to other recent genetically based estimates of mixing in the Central and Eastern North Atlantic (Puncher et al., 2018; Rodríguez-Ezpeleta et al., 2019; Rooker et al., 2019). Individuals from the western population were found in both 2014 and 2017, with the estimated total proportion among samples of approximately $10 \%$. This could be explained, to some extent, by the documented mis-assignment rate between populations using the specific SNP panel (see Rodríguez-Ezpeleta et al., 2019). However, misassignment rates between populations is not symmetrical, i.e. only $2 \%$ of individuals of known eastern origin were assigned to the western population whereas $10 \%$ from the western population were assigned to east (Rodríguez-Ezpeleta et al., 2019). Thus, a hypothesis of purely eastern Atlantic origin of bluefin tuna east of Greenland is highly unlikely, also considering that two of the three individuals were assigned with $100 \%$ probability to the western population. Still, given the low, but potential, misassignment and the limited number of samples, it is not possible to document how representative the western proportion is and how much it varies among years, thus further baseline improvements and sampling is needed to draw firm conclusions. Additionally, alternative explanations for the origin of the misassigned and unassigned individuals have been recently suggested (Brophy et al. 2020).

Tagging studies in the 1950s-1960s in eastern USA waters and more recent satellite tracking data (Block et al., 2001, 2005; Walli et al., 2009; Galuardi et al., 2010) show that bluefin tunas migrate between the North American east coast and the Northeast Atlantic. Unfortunately, the genetic origin of most of these tagged trans-Atlantic migrating individuals is not known, which could be due to the presence of a third spawning component or other causes (Brophy et al. 2020). However, based on the genetic evidence of mixed stocks (Puncher et al., 2018; Rodríguez-Ezpeleta et al., 2019), it appears that extensive mixing of the two populations is common across the species distribution and particularly in central Atlantic areas, suggesting that extensive feeding and spawning migrations are common for both populations. Given that bluefin tunas historically (Mather et al., 1995) and recently (since 2017) have been present in waters of northern Newfoundland and even Labrador (CentralVoice, 2017; CBC, 2018; DFO, 2019), and temperatures in the Irminger Sea region have been relatively warm since the 2010s (MacKenzie et al., 2014; Jansen et al., 2016), it is conceivable that some western tunas could have migrated further north and east to the Denmark Strait-Irminger Sea with relatively low thermal stress. These western tunas along with eastern individuals emigrating from 
the Mediterranean Sea and Bay of Biscay presumably all migrated to the region potentially by following and/or searching for prey such as mackerel (MacKenzie et al., 2014).

\section{Hydrographic conditions}

Surface temperatures during late summer - early autumn in the Irminger Current in Southeast Greenland have increased to an unprecedented level in the last decades (Figure a; (MacKenzie et al., 2014; Jansen et al., 2016)). Temperatures increased most in the mid/late 1990s. Temperatures since the late 1990s have become less thermally stressful for bluefin tuna than they were previously. Similarly the area of suitable thermal habitat in summer assuming two different criteria as lower temperature suitability (Mackenzie et al., 2014) has increased since the late 1990s. For example, since 1870 , the 8 years with largest area of SST $>8^{\circ} \mathrm{C}$ have occurred after 1997 . These developments have therefore opened potential (at least in terms of thermal suitability) new foraging habitat for bluefin tuna in east Greenland waters. New tagging investigations, which include temperature data storage, in northern areas would help identify the lower thermal tolerance limit of bluefin tunas and therefore facilitate quantifying the sizes and locations of thermally suitable habitats for this species, and how future climate change might affect distributions. Erauskin-Extramiana et al. (2019), based on SST and other variables, predict a northern expansion of Atlantic bluefin tuna habitat under future climate change, but additional knowledge on environmental preferences would allow to improve projections of future distributions.

The first Atlantic bluefin tuna captured in East Greenland were caught in waters close to the front between the southward flowing East Greenland Current and the Irminger Current (Mackenzie et al., 2014). The catches in subsequent years were also located in or close to this same hydrographic feature. This represents a thermal boundary to the cold tolerance of the mackerel distribution (since the fishery was targeting mackerel) and possibly an area of mackerel aggregation; mackerel are usually associated with temperatures $>8-9^{\circ} \mathrm{C}$ (Olafsdottir et al., 2019). If so, the frontal zone, where temperature changes substantially over a short distance, and waters to its immediate south, could be a stimulus for bluefin tuna aggregation and foraging.

\section{Local abundance and factors affecting presence in the Greenlandic part of the Irminger Sea}

The time series of bluefin tuna catches in East Greenland is too short for rigorous quantitative analysis of the factors affecting bluefin tuna presence in this region. However, in general, there are at least 
420 three variables which have changed in the last 5-10 years which would have increased the likelihood 421 that bluefin tuna would become seasonal guests in the waters of East Greenland (figure 3). One of 422 these is the increase in temperatures to levels which are more physiologically suitable for this species 423 than they were in the past (see previous section and figure 4a). The causes of such a rise in 424 temperature are unclear but could be at least partly associated with the overall global warming trend of recent decades. Observation that temperatures have risen intermittently and plateaued with large inter-annual fluctuations indicates that other factors may be involved. These could include changes in the relative strengths of warm and cold currents entering the region, and larger - scale oceanographic phenomena, such as the intensity and strength of the North Atlantic Subpolar Gyre which affects water masses and other biota in the region and in areas through which bluefin tuna must pass when migrating to East Greenland (Hátún et al., 2009, 2017; Post et al. 2020). Our study region is within the area represented in the Atlantic Multi-decadal Oscillation (AMO) of north Atlantic temperature, which has recently been proposed to reflect thermal habitat and affect distributions of bluefin tuna in the Atlantic Ocean (Faillettaz et al., 2019).

Furthermore, changes in prey availability, in this case particularly mackerel distribution and migration may also have had an effect on the distribution of bluefin tuna (figure $3 b$ ). This species has spread westward into Greenland waters simultaneously with the tuna and could have provided a foraging trail and stimulus for bluefin tuna to enter east Greenland waters. The range expansion of mackerel is believed to be due to a complex interaction between rising temperatures, mackerel population dynamics, and the abundances of zooplankton (Trenkel et al., 2014; Jansen, 2016; Jansen et al., 2016; Olafsdottir et al., 2019). This may therefore be regarded as a cascading spatial bottom-up effect from

Third, the overall abundance of Atlantic bluefin tuna has increased substantially in the eastern Atlantic-Mediterranean Sea (figure 4c) since a recovery plan was implemented in 2007-2008 (ICCAT, 2017a). It is possible that population increase has stimulated bluefin tuna to forage more widely to reduce density - dependent competition in more southerly areas. Larger sized fish also tend to migrate further (Nøttestad et al. 1999). This factors, combined with the increase in mackerel biomass context, the most recent years, 2019 and 2020, have somewhat unusual sets of circumstances for the 
453 region: relatively warm temperatures (Figure 3a), relatively abundant bluefin tuna stock in the 454 northeast Atlantic-Mediterranean (Figure 3b), but low biomass of a key prey (mackerel) (Figure 3b).

455 The limited availability of mackerel as a prey may or may not have affected the tuna migration.

456 Unfortunately, this effect is confounded with the likelihood of detecting tunas. The mackerel fishery 457 closed early in 2019 and 2020 due to low mackerel availability - earlier than when the bluefin tuna 458 have usually been caught in previous years. Therefore, it is possible that tuna might have migrated to 459 the region and foraged on other (e.g. mesopelagic) species, as bluefin tunas used to do in the 460 neighbouring Iceland Basin before the mackerel expansion to that region (Olafsdottir et al., 2016). 461

The expansion of Atlantic bluefin tuna distribution into Greenland waters is not a geographically isolated event. Tunas has increased in abundance in other northern summer foraging areas, including those formerly occupied but vacant for ca. 50 years. These include the Norwegian Sea (Nøttestad et al. 2020), North Sea and the Skagerrak-Kattegat, where the species has been reported since the earlymid-2010s, MacKenzie et al. 2018) As a result of these changes in distribution and abundance, Iceland and Norway now have received commercial fishing quotas (ICCAT, 2017b). In fact, as bluefin tuna continues to move north (Erauskin-Extramiana et al., 2019), the management arena might need to adapt and countries, which now host tunas, should consider ICCAT membership.

\section{Acknowledgements}

We wish to thank the commercial fishers from the pelagic fishing fleet in Greenland that provided us with information, frozen stomachs and tissue samples from their tuna bycatches. We thank Iñaki Mendibil (AZTI) for technical assistance. This study was supported by the Government of Greenland and the Nordic Council of Ministers AG-Fisk (Nordtun2: grant number 180-(2018)-Tuna tagging) and the Department of Environment, Planning, Agriculture and Fisheries of the Basque Government under the project GENPES. 
480

481

482

483

484

485

486

487

488

489

490

491

492

493

494

495

496

497

498

499

500

501

502

\section{Figures}

Figure 1. Locations of Atlantic bluefin tuna catches in Greenland waters (known positions indicated by large blue points), and catches of mackerel (small dark grey points). Contours indicate the mean sea surface temperature in August in the years with bycatches of Bluefin tuna (2012, 2014, 2015, 2017, 2018). The map was created in $R$ using the package 'lattice' v.0.20-41 (Deepayan, 2008) and 'maps' v.3.3.0 (Brownrigg et al., 2018).

Figure 2. Size distribution of Atlantic bluefin tunas caught in Greenland waters in a) length (measured), b) weight (some measured, some estimated), and c) estimated ages.

Figure 3. Time series of a) mean SST in August in the polygon indicated in Error! Reference source not found., and b) area of suitable habitat within $58-70^{\circ} \mathrm{N}$ and $20-45^{\circ} \mathrm{W}$ defined as SST $>8^{\circ} \mathrm{C}$ (blue) and SST $>11^{\circ} \mathrm{C}$ (red). Blue and red lines indicates running means (see material and methods) and the black lines indicates the mean over all years.

Figure 4. Time series of normalized values of bluefin tuna CPUE (= numbers caught * mackerel catch-1) together with a) bluefin tuna SSB from ICCAT stock assessment (ICCAT, 2017a), b) mean SST in august and c) mackerel abundance in East Greenlandic (from pelagic trawl survey IESSNS with assumed 0 before the first mackerel observation in 2011).

\section{Tables}

\begin{tabular}{|c|c|c|c|c|c|c|c|}
\hline Year & $\begin{array}{c}\text { No. } \\
\text { caught }\end{array}$ & $\begin{array}{c}\text { Date } \\
\text { of first } \\
\text { tuna } \\
\text { capture }\end{array}$ & $\begin{array}{c}\text { Date } \\
\text { of last tuna } \\
\text { capture }\end{array}$ & $\begin{array}{c}\text { No of } \\
\text { stomachs }\end{array}$ & $\begin{array}{c}\text { No. of } \\
\text { genetic } \\
\text { samples }\end{array}$ & $\begin{array}{c}\text { Mackerel } \\
\text { catch (t) }\end{array}$ & $\begin{array}{c}\text { Mackerel } \\
\text { biomass } \\
\text { index in } \\
\text { East } \\
\text { Greenland }\end{array}$ \\
\hline 2012 & 3 & 22 Aug. & 22 Aug. & 0 & 0 & 5458 & $*$ \\
\hline 2013 & 0 & - & - & 0 & 0 & 54150 & $*$ \\
\hline 2014 & 55 & 24 Aug. & 16 Sept. & 10 & 21 & 78580 & 1164 \\
\hline 2015 & 10 & 13 Aug. & 20 Aug. & 1 & 7 & 30429 & 321 \\
\hline 2016 & 0 & - & - & 0 & 0 & 36190 & 1026 \\
\hline 2017 & 12 & 15 Aug. & 19 Aug. & 7 & 6 & 36753 & 530 \\
\hline 2018 & 4 & 11 Aug. & Early Sept. & 0 & 0 & 53132 & 293 \\
\hline
\end{tabular}




\begin{tabular}{|l|c|c|c|c|c|c|c|}
\hline 2019 & 0 & - & - & 0 & 0 & 6624 & 15 \\
\hline 2020 & 0 & - & - & 0 & 0 & 0.014 & 0 \\
\hline Total & 84 & - & - & 18 & 34 & - & - \\
\hline
\end{tabular}

503

504 505 506 507 508
Table 1. Observations and samples of Atlantic bluefin tuna in East Greenland (ICES area 14b) in 20122020. *Pelagic trawl survey of mackerel biomass started in 2014. 


\section{References}

Astthorsson, O. S., Valdimarsson, H., Gudmundsdottir, A., and Oskarsson, G. J. 2012. Climate-related variations in the occurrence and distribution of mackerel (Scomber scombrus) in Icelandic waters. ICES Journal of Marine Science, 69: 12891297.

Birnie-Gauvin, K., MacKenzie, B. R., and Aarestrup, K. 2018. Electronic tagging of bluefin tunas in Scandinavian waters 2018. ICCAT Coll.Vol.Sci.Papers SCRS/2018/178, xx: 6 pp.

Birnie-Gauvin, K., Baktoft, H., MacKenzie, B. R., and Aarestrup, K. 2019. Tagging of Atlantic bluefin tunas with electronic tags in Skagerrak in 2019: a brief summary (contract report to ICCAT). 1-6 pp.

Block, B. A., Dewar, H., Blackwell, S. B., Williams, T. D., Prince, E. D., Farwell, C. J., Boustany, A., et al. 2001. Migratory movements, depth preferences, and thermal biology of Atlantic bluefin tuna. Science, 293: 1310-1314.

Block, B. A., Teo, S. L. H., Walli, A., Boustany, A., Stokesbury, M. J. W., Farwell, C. J., Weng, K. C., et al. 2005. Electronic tagging and population structure of Atlantic bluefin tuna. Nature, 434: 1121-1127.

Brownrigg, R., Minka, T.P., and Deckmyn A. 2018. maps: Draw Geographical Maps. https://CRAN.R-project.org/package=maps.

Boyce, D. G., Tittensor, D. P., and Worm, B. 2008. Effects of temperature on global patterns of tuna and billfish richness. Marine Ecology Progress Series, 355: 267-276.

Brophy, D., Rodríguez-Ezpeleta, N., Fraile, I. and H. Arrizabalaga. 2020. Combining genetic markers with stable isotopes in otoliths reveals complexity in the stock structure of Atlantic bluefin tuna (Thunnus thynnus). Sci Rep 10, 14675. https://doi.org/10.1038/s41598-020-71355-6

CBC. 2018. Tuna flips for the seafood special in Holyrood.

CentralVoice. 2017. Rare bluefin tuna washes ashore in Red Bay.

Chase, B. C. 2002. Differences in diet of Atlantic bluefin tuna (Thunnus thynnus) at five seasonal feeding grounds on the New England continental shelf. Fishery Bulletin, 100: $168-180$.

Cort, J. L. 1991. Age and growth of the bluefin tuna (Thunnus thynnus thynnus) of the 
Northeast Atlantic. Col.Vol.Sci.Pap.ICCAT, 35: 213-230.

Cury, P., Anneville, O., Bard, F. X., Fonteneau, A., and Roy, C. 1998. Obstinate north Atlantic bluefin tuna (Thunnus thynnus thynnus): an evolutionary perspective to consider spawning migration. ICCAT Coll.Vol.Sci.Papers (Proc.of ICCAT Tuna Symposium 1998, Part 1), 50: 239-247.

De Luca, G., Mariani, P., MacKenzie, B. R., and Marsili, M. 2014. Fishing out collective memory of migratory schools. Journal of the Royal Society Interface, 11: doi: 10.1098/rsif.2014.0043.

Deepayan, Sarkar. 2008. Lattice: Multivariate Data Visualization with R, Springer. http://lmdvr.r-forge.r-project.org/

DFO. 2019. Fisheries licensing policy Newfoundland and Labrador region. 1-58 pp.

Erauskin-Extramiana, M., Arrizabalaga, H., Hobday, A. J., Cabré, A., Ibaibarriaga, L., Arregui, I., Murua, H., et al. (2019). Large-scale distribution of tuna species in a warming ocean. Global Change Biology, 25(6): 2043-2060.

Faillettaz, R., Beaugrand, G., Goberville, E., and Kirby, R. R. 2019. Atlantic Multidecadal Oscillations drive the basin-scale distribution of Atlantic bluefin tuna. Science Advances, 5: eaar6993.

Fromentin, J.-M., Reygondeau, G., Bonhommeau, S., and Beaugrand, G. 2013. Oceanographic changes and exploitation drive the spatio-temporal dynamics of Atlantic bluefin tuna (Thunnus thynnus). Fisheries Oceanography, 23: 147-156.

Galuardi, B., Royer, F., Golet, W., Logan, J., Neilson, J., and Lutcavage, M. 2010. Complex migration routes of Atlantic bluefin tuna (Thunnus thynnus) question current population structure paradigm. Canadian Journal of Fisheries and Aquatic Sciences, 67: 966-976. ISI:000279224900005.

GFLK. 2014. No Title. GFLK årsrapporter (annual reports).

Hamre, J. 1958. Tuna investigations in Norwegian coastal waters 1954-1958. Ann.Biologiques (ICES), 15: 197-211.

Hamre, J., Lozano, F., Rodriguez-Roda, J., and Tiews, K. 1966. Report from the bluefin tuna working group. ICES Stat.Newsletter, 26: 1-34.

Hansen, F. T., Burns, F., Post, S., Thygesen, U. H., and Jansen, T. 2018. Length measurement methods of Atlantic mackerel (Scomber scombrus) and Atlantic horse mackerel (Trachurus trachurus) - current practice, conversion keys and recommendations. Fisheries 
Research, 205: 57-64.

Hátún, H., Payne, M. R., Beaugrand, G., Reid, P. C. C., Sandø, A. B. B., Drange, H., Hansen, B., et al. 2009. Large bio-geographical shifts in the north-eastern Atlantic Ocean: From the subpolar gyre, via plankton, to blue whiting and pilot whales. Prog.Oceanogr., 80: 149-162. Elsevier Ltd. http://linkinghub.elsevier.com/retrieve/pii/S0079661109000135.

Hátún, H., Olsen, B., and Pacariz, S. 2017. The dynamics of the North Atlantic Subpolar Gyre introduces predictability to the breeding success of kittiwakes. Frontiers in Marine Science, 4 .

Heithaus, M. R., A, F., J, W. A., and Worm B. 2008. Predicting ecological consequences of marine top predator declines. Trends in Ecology \& Evolution, 23: 202-210.

ICCAT. 2017a. Report of the 2017 ICCAT bluefin stock assessment meeting (Madrid, Spain 20-28 July, 2017). Madrid, Spain. 1-106 pp.

ICCAT. 2017b. Report of the Standing Committee on Research and Statistics (SCRS), Madrid, Spain, 2-6 October, 2017. Madrid, Spain. 1-435 pp.

ICES. 2018. Report of the Working Group on Widely Distributed Stocks (WGWIDE). ICES CM 2018/ACOM:23.

ICES. 2019. ICES Working Group of International Pelagic Surveys (WGIPS). ICES Scientific Reports. 1:11. 493 pp. http://doi.org/10.17895/ices.pub.5122

IPCC. 2019. Summary for Policymakers. In: IPCC Special Report on the Ocean and Cryosphere in a Changing Climate [H.- O. Pörtner, D.C. Roberts, V. Masson-Delmotte, P. Zhai, M. Tignor, E. Poloczanska, K. Mintenbeck, M. Nicolai, A. Okem, J. Petzold, B. Rama, N. Weyer (e.

Jansen, T., Post, S., Kristiansen, T., Óskarsson, G. J., Boje, J., MacKenzie, B. R., Broberg, M., et al. 2016. Ocean warming expands habitat of a rich natural resource and benefits a national economy. Ecological Applications, 26: 1-12.

Jansen, T. 2016. First-year survival of North East Atlantic mackerel (Scomber scombrus) from 1998 to 2012 appears to be driven by availability of Calanus, a preferred copepod prey. Fisheries Oceanography, 25: 457-469.

Jansen, T., Post, S., Olafsdottir, A. H., Reynisson, P., Óskarsson, G. J., and Arendt, K. E. 2019. Diel vertical feeding behaviour of Atlantic mackerel (Scomber scombrus) in the Irminger current. Fisheries Research, 214: 25-34.

Kathena, J. N., Yemane, D., Bahamon, N., and Jansen, T. 2018. Population abundance and 
seasonal migration patterns indicated by commercial catch-per-unit-effort of hakes (Merluccius capensis and M. paradoxus) in the northern Benguela Current Large Marine Ecosystem. African journal of marine science, 40: 197-209. Taylor \& Francis.

Kvamme, L. 2014. Superfisken er tilbake: verdens største tunfisk, makrellstørjen, skal igjen fiskes langs norskekysten. Bergens Tidende.

MacCall, A. 1990. Dynamic biogeography of fish populations. Washington Sea Grant, Seattle. $1-153 \mathrm{pp}$.

MacKenzie, B. R., and Myers, R. A. 2007. The development of the northern European fishery for north Atlantic bluefin tuna (Thunnus thynnus) during 1900-1950. Fisheries Research (Amsterdam), 87: 229-239 (doi:10.1016/j.fishres.2007.01.013). $<\mathrm{U}>$ doi:10.1016/j.fishres.2007.01.013</U>.

MacKenzie, B. R., Payne, M. R., Boje, J., Høyer, J. L., and Siegstad, H. 2014. A cascade of warming impacts brings bluefin tuna to Greenland waters. Global Change Biology, 20: 2484-2491. Wiley Online Library.

MacKenzie, B. R., Aarestrup, K., Birnie-Gauvin, K., Cardinale, M., Casini, M., Harkes, I., Onandia, I., et al. 2018. Electronic tagging of adult bluefin tunas by sport fishery in the Skagerrak, 2017. ICCAT Coll.Vol.Sci.Papers SCRS/P/2018/164, x: 18 pp.

Mather, F. J., Mason, J. M., and Jones, A. C. 1995. Historical document: life history and fisheries of Atlantic bluefin tuna. NOAA Technical Memorandum NMFS-SEFSC, 370: 1-165. US Department of Commerce, NOAA, NMFS, Southeast Fisheries Science Center.

Melvin, G. D., and Minch, T. 2018. Update of the Gulf of St. Lawrence Atlantic bluefin tuna fishery independent acoustic index of abundance. ICCAT Coll.Vol.Sci.Papers/SCRS / 2018 / 180, x: 1-16.

Nøttestad, L., Salthaug, A., Johansen, G. O., Anthonypillai, V., Tangen, Ø., Sveinbjörnsson, S., Óskarsson, G. J., et al. 2013. Cruise report from the coordinated ecosystem survey (IESSNS) with M/V ”Libas, M/V “Eros”, M/V “Finnur Fríði” and R/V “Árni Friðriksson" in the Norwegian Sea and surrounding waters, 2 July - 9 August 2013. ICES CM 2013/ACOM:15:WD.

Nøttestad, L., Utne, K. R., Óskarsson, G. J., Jónsson, S. P., Jacobsen, J. A., Tangen, Ø., Anthonypillai, V., et al. 2016. Quantifying changes in abundance, biomass, and spatial distribution of Northeast Atlantic mackerel ( Scomber scombrus ) in the Nordic seas from 
2007 to 2014. ICES Journal of Marine Science: Journal du Conseil, 73: 359-373.

Nøttestad, L., Anthonypillai, V., Vatnehol, S., Salhaug, A., Høines, Å., Ólafsdóttir, A., Kennedy, J., et al. 2019. Cruise report from the International Ecosystem Summer Survey in the Nordic Seas (IESSNS) 28th June - 5th August 2019. ICES CM 2019/ACOM:16/WD5: 1-51.

Nøttestad, L., Anthonypillai, V., Salhaug, A., Høines, Å., Ólafsdóttir, A., Kennedy, J., Homrum, E., et al. 2020. Cruise report from the International Ecosystem Summer Survey in the Nordic Seas (IESSNS) 1th July - 4th August 2020. ICES CM 2020/ACOM:xx/WD5: 1-55.

Olafsdottir, A. H., Utne, K. R., Jacobsen, J. A., Jansen, T., Óskarsson, G. J., Nøttestad, L., Elvarsson, B. P., et al. 2019. Geographical expansion of Northeast Atlantic mackerel (Scomber scombrus) in the Nordic Seas from 2007 to 2016 was primarily driven by stock size and constrained by low temperatures. Deep Sea Research Part II: Topical Studies in Oceanography, 159: 152-168.

Olafsdottir, D., MacKenzie, B. R., Chosson-P, V., and Ingimundardottir, T. 2016. Dietary Evidence of Mesopelagic and Pelagic Foraging by Atlantic Bluefin Tuna (Thunnus thynnus L.) during Autumn Migrations to the Iceland Basin. Frontiers in Marine Science, 3: 108 (doi:10.3389/fmars.2016.00108).

Petitgas, P., Secor, D. H., McQuinn, I., Huse, G., and Lo, N. 2010. Stock collapses and their recovery: mechanisms that establish and maintain life-cycle closure in space and time. ICES Journal of Marine Science, 67: 1841-1848. OXFORD UNIV PRESS, [Petitgas, Pierre] IFREMER, F-44311 Nantes 3, France. [Secor, Dave H.] UMCES, CBL, Solomons Isl, MD 20688 USA. [McQuinn, Ian] IML, DFO, Mont Joli, PQ G5H 3Z4, Canada. [Huse, Geir] IMR, N-5817 Bergen, Norway. [Lo, Nancy] NOAA, SWFSC, La Jolla, CA 92037 USA.

Pleizier, N. K., Campana, S. E., Schallert, R. J., Wilson, S. G., and Block, B. A. 2012. Atlantic bluefin tuna (Thunnus thynnus ) diet in the Gulf of St. Lawrence and on the Eastern Scotian Shelf. Journal of Northwest Atlantic Fishery Science, 44: 67-76.

Post, S., Werner, K.-M., Núñez-Riboni, I., Charfik, L., Hátún, H., and Jansen, T. 2020.

Subpolar gyre and temperature drive boreal fish abundance in Greenland waters. Fish and Fisheries. Doi: 10.1111/faf.12512.

Puncher, G. N., Cariani, A., Maes, G. E., Van Houdt, J., Herten, K., Cannas, R., Rodriguez- 
Ezpeleta, N., et al. 2018. Spatial dynamics and mixing of bluefin tuna in the Atlantic Ocean and Mediterranean Sea revealed using next-generation sequencing. Molecular Ecology Resources, 18: 620-638.

Rayner, N. A., Parker, D. E., Horton, E. B., Folland, C. K., Alexander, L. V, and Rowell, D. P. 2003. Global analyses of sea surface temperature, sea ice and night marine air temperature since the late nineteenth century. J.Geophys.Res., 108: 4407-doi: 10.1029/2002JD002670 (updates available.

Richardson, D. E., Marancik, K. E., Guyon, J. R., Lutcavage, M. E., Galuardi, B., Lam, C. H., Walsh, H. J., et al. 2016. Discovery of a spawning ground reveals diverse migration strategies in Atlantic bluefin tuna (Thunnus thynnus). Proceedings of the National Academy of Sciences of the United States of America, 113: 3299-3304.

Rodriguez-Marin, E., Ortiz, M., Ortiz de Urbina, J. M., Quelle, P., Walter, J., Abid, N., Addis, P., et al. 2015. Atlantic bluefin tuna (Thunnus thynnus) biometrics and condition. PLOS ONE, 10: e0141478.

Rodríguez-Roda, J. 1964. Biologia del atun, Thunnus thynnus (L.), de la costa sudatlantica de Espana. Inv. Pesq, 25: 33-146.

Rodríguez-Ezpeleta, N., Díaz-Arce, N., Walter, J. F., Richardson, D. E., Rooker, J. R., Nøttestad, L., Hanke, A. R., et al. 2019. Determining natal origin for improved management of Atlantic bluefin tuna. Frontiers in Ecology and the Environment, 17: 439444.

Rooker, J. R., Bremer, J. R. A., Block, B. A., Dewar, H., De Metrio, G., Corriero, A., Kraus, R. T., et al. 2007. Life history and stock structure of Atlantic bluefin tuna (Thunnus thynnus). Reviews in Fisheries Science, 15: 265-310. ISI:000251600400001.

Rooker, J. R., Secor, D. H., De Metrio, G., Schlosser, R., Block, B. A., Nielson, J. D., Schloesser, R., et al. 2008. Natal Homing and Connectivity in Atlantic Bluefin Tuna Populations. Science, 322: 742-744. http://www.sciencemag.org/cgi/doi/10.1126/science.1161473.

Rooker, J. R., Fraile, I., Liu, H., Abid, N., Dance, M. A., Itoh, T., Kimoto, A., et al. 2019. Wide-Ranging Temporal Variation in Transoceanic Movement and Population Mixing of Bluefin Tuna in the North Atlantic Ocean. Frontiers in Marine Science, 6.

Sørensen, C. 2015. sej tun high.

Teo, S. L. H., Boustany, A., Dewar, H., Stokesbury, M. J. W., Weng, K. C., Beemer, S., Seitz, 
A. C., et al. 2007. Annual migrations, diving behavior, and thermal biology of Atlantic bluefin tuna, Thunnus thynnus, on their Gulf of Mexico breeding grounds. Marine Biology, 151: 1-18. ISI:000244485800001.

Tiews, K. 1978. On the disappearance of bluefin tuna in the North Sea and its ecological implications for herring and mackerel. Rapp. P.-v. Reun. Cons.i nt. Explor. Mer., 172: 301-309.

Trenkel, V. M., Huse, G., MacKenzie, B. R., Alvarez, P., Arrizabalaga, H., Castonguay, M., Goñi, N., et al. 2014. Comparative ecology of widely distributed pelagic fish species in the North Atlantic: Implications for modelling climate and fisheries impacts. Progress in Oceanography, 129: 219-243.

Uranga, J., Arrizabalaga, H., Boyra, G., Hernandez, M. C., Goñi, N., Arregui, I., Fernandes, J. A., et al. 2017. Detecting the presence-absence of bluefin tuna by automated analysis of medium-range sonars on fishing vessels. PLOS ONE, 12: e0171382. Public Library of Science.

Uranga, J., Arrizabalaga, H., Boyra, G., Hernandez, C., and Goñi, N. 2019. Counting and sizing Atlantic bluefin tuna schools using medium range sonars of baitboats in the Bay of Biscay. Continental Shelf Research, 182: 37-45. Elsevier Ltd. https://doi.org/10.1016/j.csr.2019.05.013.

Vanderlaan, A. S. M., Hanke, A. R., Chasse, J., and Neilson, J. D. 2014. Environmental influences on Atlantic bluefin tuna (Thunnus thynnus) catch per unit effort in the southern Gulf of St. Lawrence. Fisheries Oceanography, 23: 83-100.

Walli, A., Teo, S. L. H., Boustany, A., Farwell, C. J., Williams, T., Dewar, H., Prince, E., et al. 2009. Seasonal Movements, Aggregations and Diving Behavior of Atlantic Bluefin Tuna (Thunnus thynnus) Revealed with Archival Tags. Plos One, 4: e6151-e6151. 


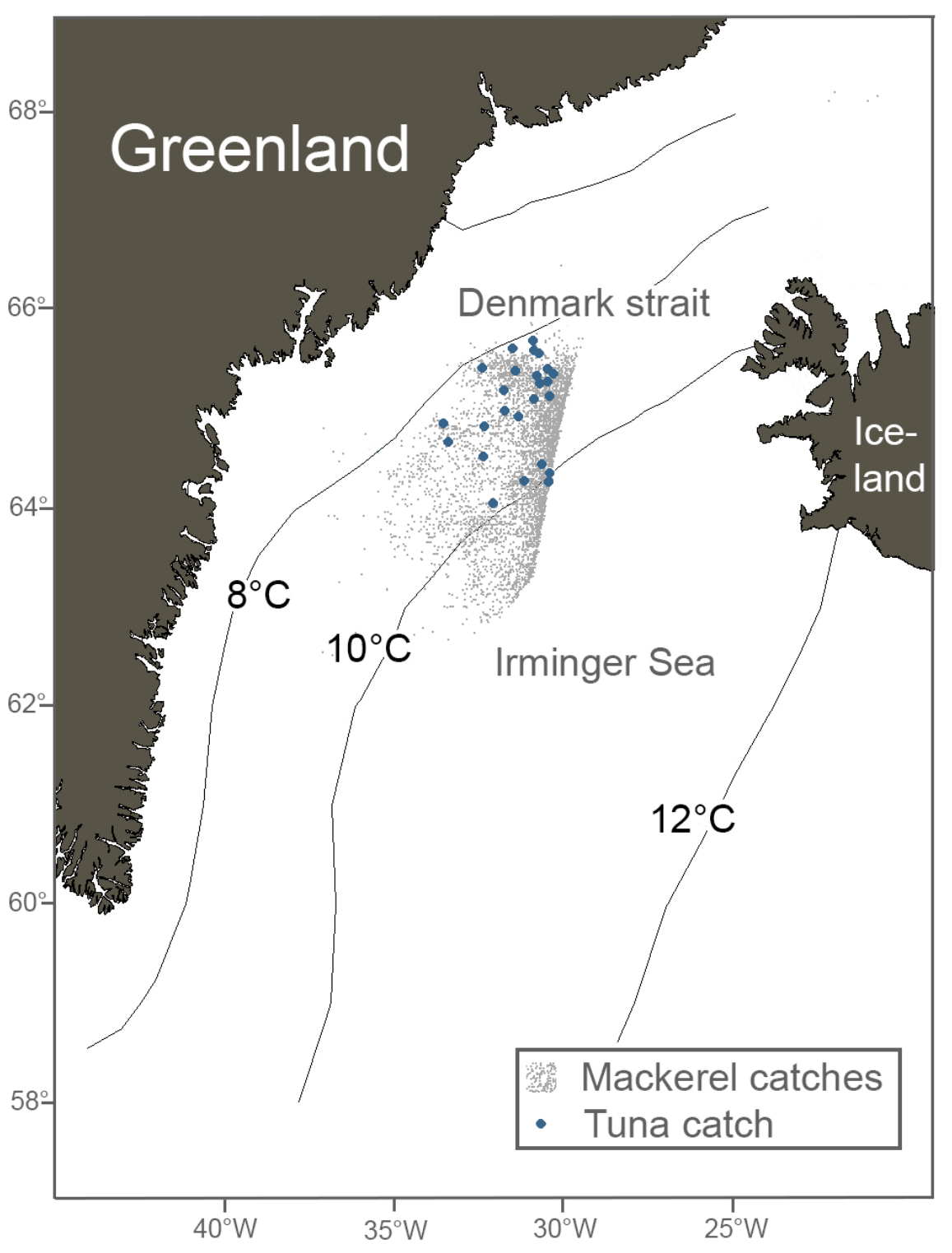


(a)

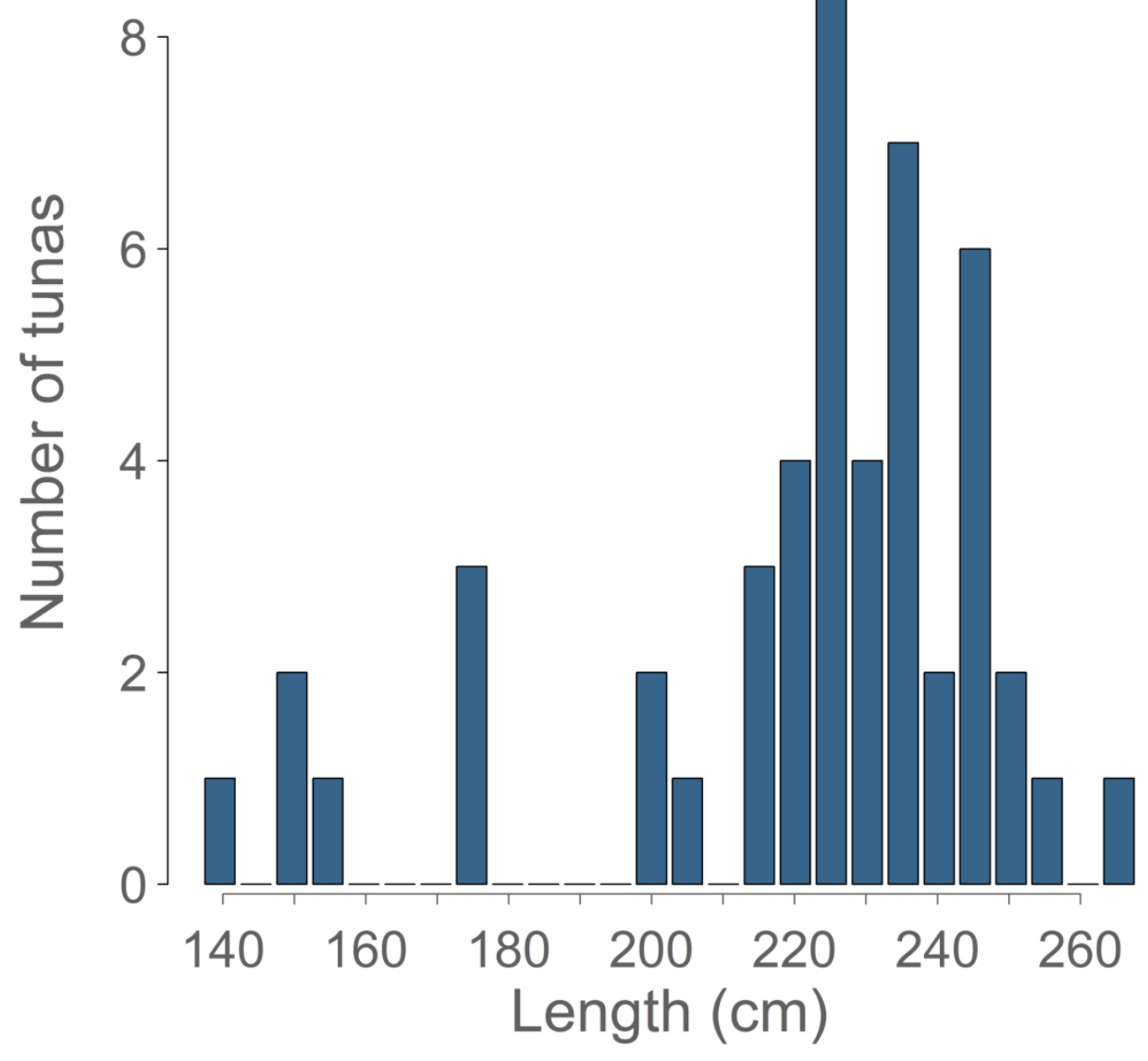

$199 \times 199 \mathrm{~mm}(300 \times 300 \mathrm{DPI})$ 


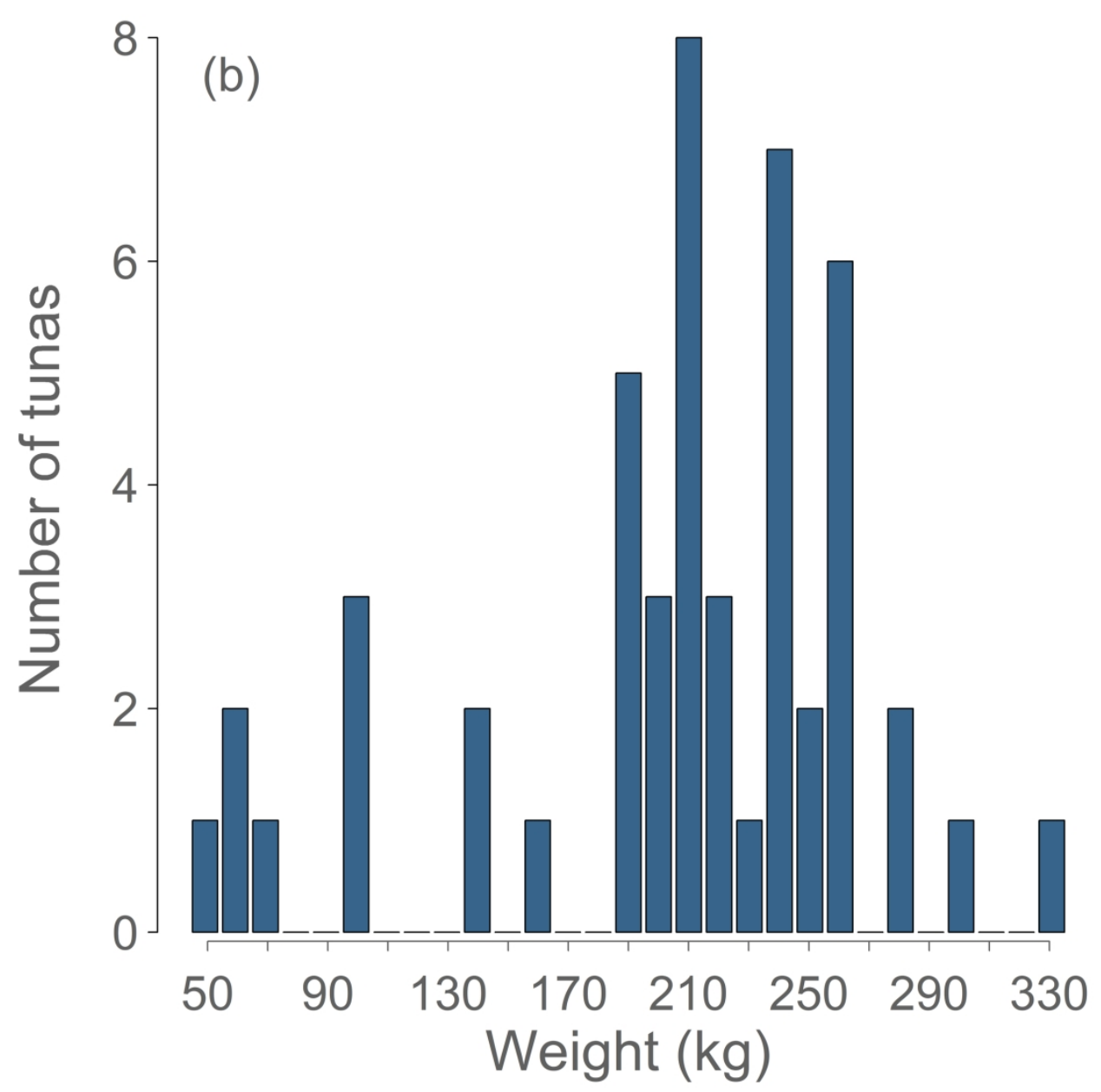

$199 \times 199 m m(300 \times 300$ DPI $)$ 


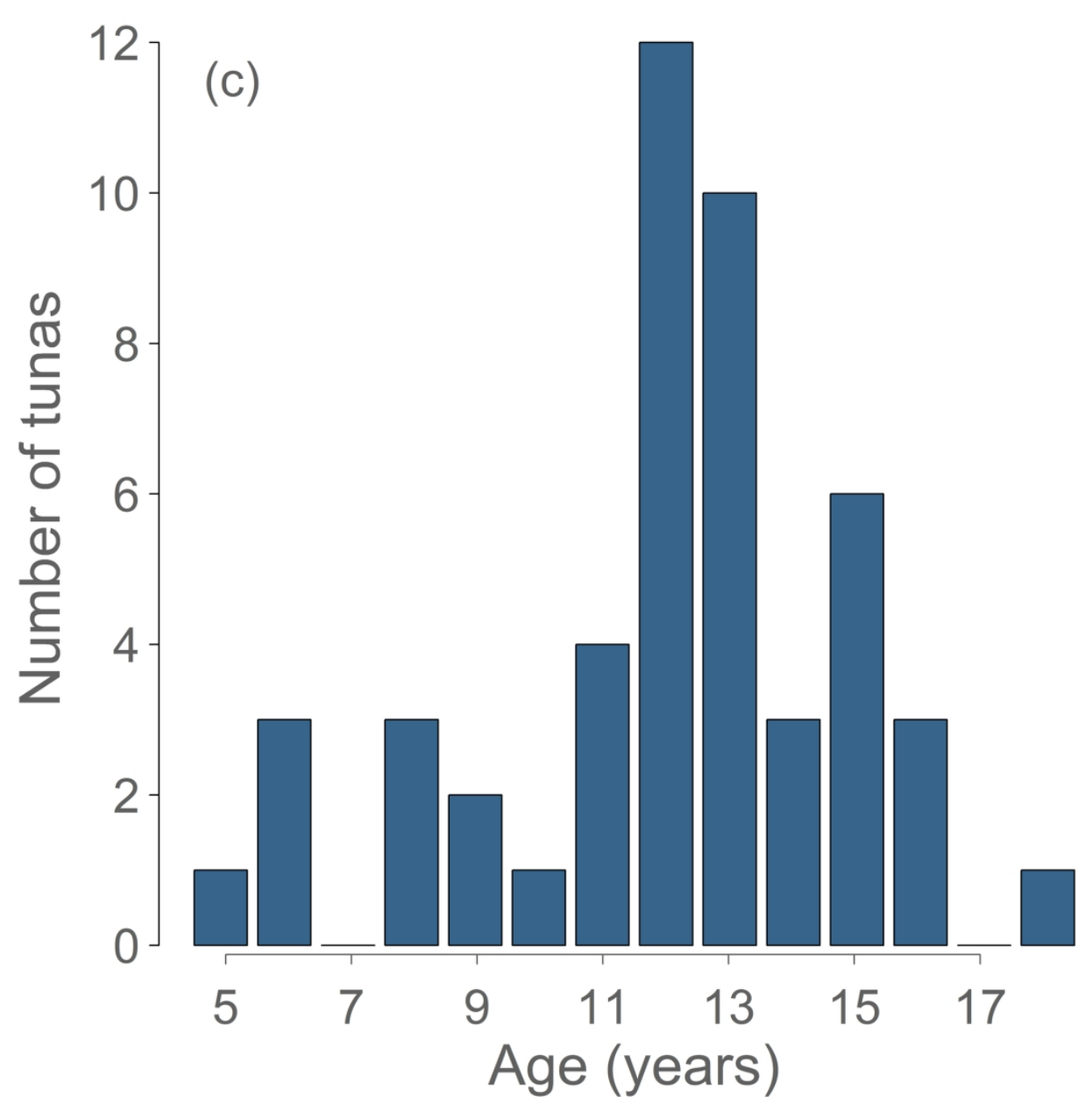

$199 \times 199 \mathrm{~mm}(300 \times 300$ DPI $)$ 
(a)

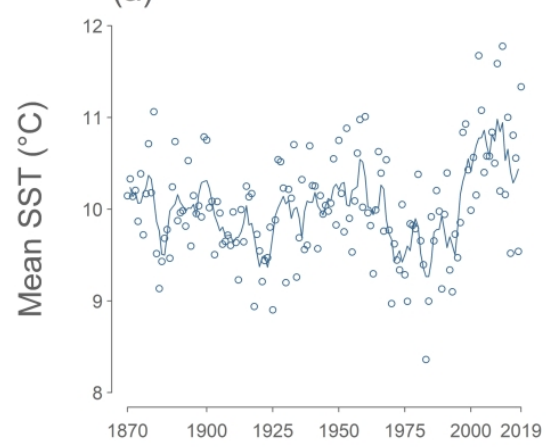

(b)

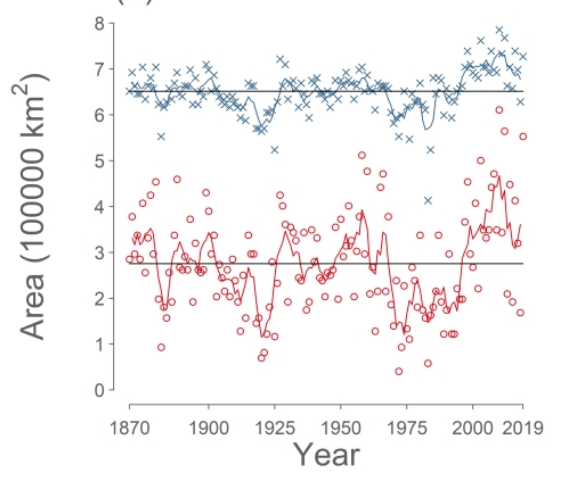

$149 \times 387 \mathrm{~mm}(300 \times 300 \mathrm{DPI})$

( ) The Author(s) or their Institution(s) 
(a)

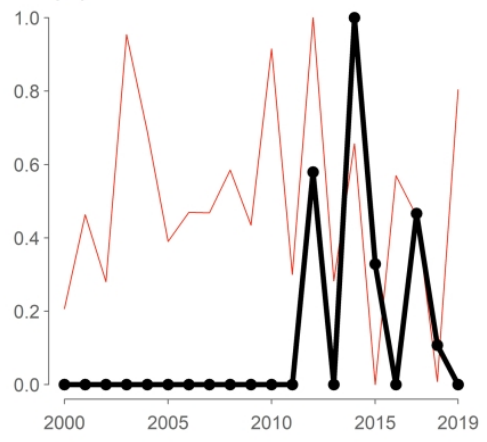

(b)

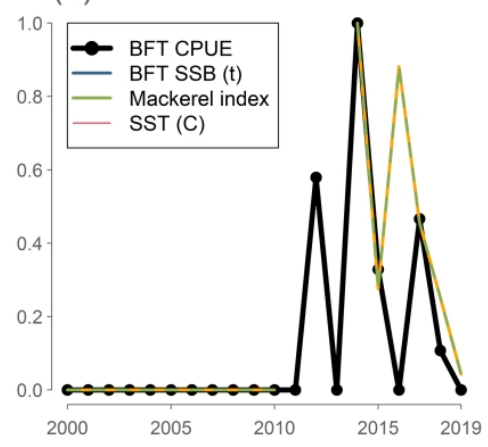

(c)

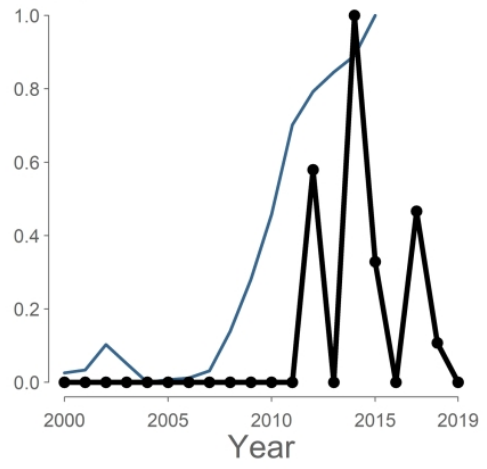

$149 \times 387 \mathrm{~mm}(300 \times 300 \mathrm{DPI})$ 